\title{
Correspondence
}

https://doi.org/10.11646/phytotaxa.395.2.7

\section{To be or not to be: On the usefulness of infraspecific names in Heterocapsa steinii (Heterocapsaceae, Peridiniales)}

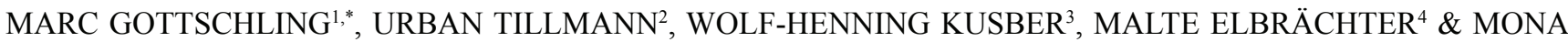 \\ HOPPENRATH ${ }^{5}$ \\ ${ }^{1}$ Department Biologie, Systematische Botanik und Mykologie, GeoBio-Center, Ludwig-Maximilians-Universität München, Menzinger \\ Str. 67, D-80638 München, Germany \\ ${ }^{2}$ Alfred-Wegener-Institut, Helmholtz-Zentrum für Polar- und Meeresforschung, Am Handelshafen 12, D - 27570 Bremerhaven, Germany \\ ${ }^{3}$ Botanischer Garten und Botanisches Museum Berlin, Freie Universität Berlin, Königin-Luise-Straße 6-8, D - 14195 Berlin, Germany \\ ${ }^{4}$ Alfred-Wegener-Institut, Helmholtz-Zentrum für Polar- und Meeresforschung, Wattenmeerstation Sylt, Hafenstr. 43, D - 25992 List/ \\ Sylt, Germany \\ ${ }^{5}$ Senckenberg am Meer, German Centre for Marine Biodiversity Research (DZMB), Südstrand 44, D- 26382 Wilhelmshaven, Germany \\ *corresponding author, e-mail: gottschling@bio.lmu.de
}

Erich Lindemann (1888-1945) was a prolific phycologist in the first half of the $20^{\text {th }}$ century and described many new dinophyte taxa in his times. He also observed some infraspecific variation in Heterocapsa steinii Tillmann, Gottschling, Hoppenrath, Kusber \& Elbr. (legitimate name for 'Heterocapsa triquetra' sensu Stein 1883) and introduced a new variety and two new forms as well (Fig. 1). Lindemann (1920: 182) put attention on the relations between the first apical and precingular plates: In his concept, plate 1' of 'true' H. steinii is small and has no contact to plate 1" while in H. triquetra var. litoralis Er.Lindem., it is bigger and shares an extensive suture to plate 1". The forms (Lindemann, 1924a: 115-116) were based on the presence of an apical pore complex (APC) distinctly visible in light microscopy (H. triquetra forma apiculata Er.Lindem., nom. illeg., H. triquetra var. litoralis forma apiculata Er.Lindem.). Cells without discernible APC were characterised as having a 'pseudoapex' (Lindemann 1919: 216), but such concept was not adopted by subsequent authors.

After more than a century of research on $H$. steinii, cells with a 'pseudoapex' have never been observed again (Tillmann et al. 2017). In fact, a dinophyte species exhibiting variability regarding this feature (i.e., thecate cells either with or without APC in the same population) is not yet documented unequivocally. It is most likely that Lindemann (1924a, b) overlooked the flat and inconspicuous APC (particularly in his early report: Lindemann 1920). Similarly, E. Lindemann's interpretation of F. von Stein's species (i.e., no contact between plates 1' and 1": Lindemann 1924a) was - to the best of our knowledgenever observed by subsequent researchers. The erection of the variety remains also elusive, as the original illustrations of Stein (1883) show the presumptive diagnostic trait precisely of $H$. triquetra var. litoralis and the first apical plate in contact with the first precingular plate. Thus, neither the variety nor Heterocapsa triquetra forma apiculata appear to be existent in nature, and Heterocapsa triquetra [var. litoralis] forma apiculata corresponds exactly to what was already illustrated forty years earlier (Stein 1883).

The question arises how the infraspecific names of $H$. steinii should be used in future. In any case, the species name H. steinii is not threatened as for priority, infraspecific names outside the rank, in which they are published, do not compete with epithets of species accordingly to the International Code of Nomenclature for algae, fungi, and plants (ICN; Turland et al. 2018: Art. 11.2). Moreover, the names of two infraspecific taxa within the same species are homonyms, if they are not based on the same type but have the same final epithet (Turland et al. 2018: Art. 53.5) that thus, one of the two <apiculata> names is illegitimate. To the best of our knowledge, only Lindemann (1924a, b) used both names but no other author any of them. We here designate $H$. triquetra [var. triquetra] forma apiculata, nom. illeg., as the one to be rejected in accordance with Turland et al. (2018: Art. 53.5), because it is probably an artificial taxon. The present decision is also advised, as this name is not substantiated by original material (i.e., no illustration and physical material unavailable). Of the two remaining names, $H$. triquetra [var. litoralis] forma apiculata cannot be distinguished from $H$. steinii, whereas $H$. triquetra var. litoralis appears as an artificial taxon again. We here sink such names in synonymy under $H$. steinii, but they remain available for taxonomy. They may prove useful once, for example, cryptic diversity within a $H$. steinii species complex is uncovered. 


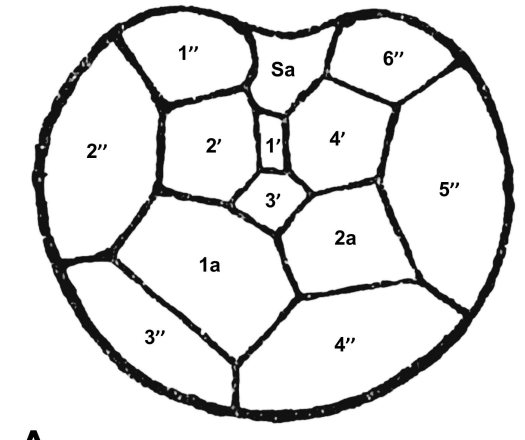

A

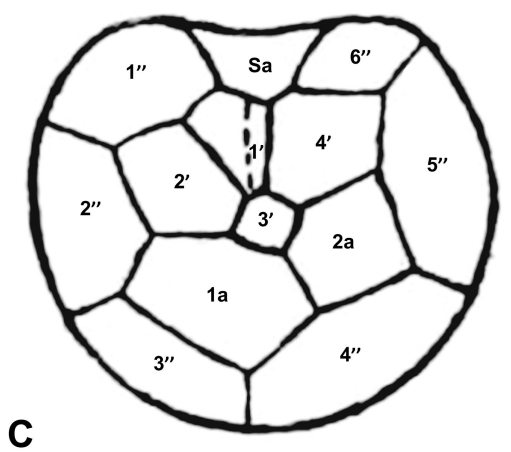

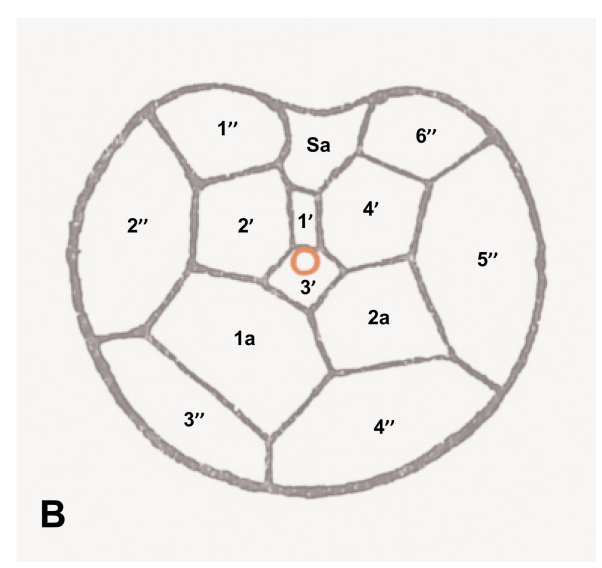

D

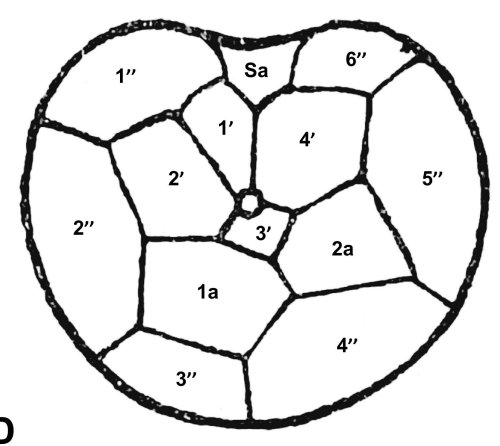

FIGURE 1. Illustrations of infraspecific variations within Heterocapsa steinii (reprinted from Lindemann 1920, 1924a), with interpretative plate labelling. A. 'Heterocapsa triquetra'sensu Stein (1883) in the interpretation of Lindemann (1924a, b). B. Heterocapsa triquetra [var. triquetra] forma apiculata, nom. illeg. (note that this illustration is not provided by Lindemann 1924a and is here interpreted based on his description, with the APC highlighted as red circle). C. Heterocapsa triquetra var. litoralis (lectotype); the dashed line indicates (wrongly) the original form in the interpretation of Lindemann (1924a, b; see Fig. 1A). D. Heterocapsa triquetra var. litoralis forma apiculata (lectotype). Note that Fig. 1A-C are probably inexistent in nature and that Fig. 1D cannot be differentiated from Heterocapsa steinii (Tillmann et al. 2017).

\section{Nomenclature and taxonomic activity}

Heterocapsa steinii Tillmann, Gottschling, Hoppenrath, Kusber \& Elbr., Journal of Phycology 53: 1320, Fig. 1N. 2017.—Type: Baltic Sea, off Germany: either Kiel or Wismar, probably late summer 1879 according to Wetzel (1885) [non-fossil]: pl. III: fig. 35! in Stein (1883) (holotype). Baltic Sea, off Germany: Schleswig Holstein, Kiel (54.32 N, 10.15²), 7 Aug 2013 [non-fossil]: A. Tillmann [U. Tillmann] UTKG7 (epitype: CEDiT2017E65!, isoepitype: CEDiT2017E66!).

= Heterocapsa triquetra var. litoralis Er.Lindem., nom. corr. (Turland et al., 2018: Art. 32.2), syn. nov., Archiv für Naturgeschichte 84.8: 182, Fig. 200. 1920.-Type: Baltic Sea, off Federal Republic of Germany. Mecklenburg-Western Pomerania, Rostock, 13 Oct 1917 [non-fossil]: Fig. 200! (reproduced here as Fig. 1C) in Lindemann (1920) (lectotype, designated here). (registered in PhycoBank under http://phycobank.org/100530)

= Heterocapsa triquetra [var. triquetra] forma apiculata Er.Lindem., nomen illegitimum (designated here according to Turland et al., 2018: Art. 53.5), syn. nov., Botanisches Archiv. Zeitschrift für die gesamte Botanik 5: 115[-116]. 1924.-Type: Mediterranean Sea, off Turkey. Marmara, Istanbul, Golden Horn [non-fossil, no original material known]. (registered in PhycoBank under http:// phycobank.org/100532)

= Heterocapsa triquetra [var. litoralis] forma apiculata Er.Lindem., nom. corr. (Turland et al., 2018: Art. 32.2), syn. nov., Botanisches Archiv. Zeitschrift für die gesamte Botanik 5: 116, Fig. 11. 1924.-Type: Mediterranean Sea, off Turkey. Marmara, Istanbul, Golden Horn, May 1918 [non-fossil]: Fig. 11! (reproduced here as Fig. 1D) in Lindemann (1924a) (lectotype, designated here). (registered in PhycoBank under http://phycobank.org/100533) 


\section{References}

Lindemann, E. (1919) Untersuchungen über Süßwasserperidineen und ihre Variationsformen. Archiv für Protistenkunde 39: $209-262$.

Lindemann, E. (1920) Untersuchungen über Süßwasserperidineen und ihre Variationsformen II. Archiv für Naturgeschichte 84 (8): $121-$ 194.

Lindemann, E. (1924a) Der Bau der Hülle bei Heterocapsa und Kryptoperidinium foliaceum (Stein) n. nom. Botanisches Archiv 5: 114120.

Lindemann, E. (1924b) Peridineen aus dem Goldenen Horn und Bosporus. Botanisches Archiv 5: 216-233.

Stein, F.R.v. (1883) Der Organismus der Infusionsthiere nach eigenen Forschungen in systematischer Reihenfolge bearbeitet 3.2. Engelmann, Leipzig.

Tillmann, U., Hoppenrath, M., Gottschling, M., Kusber, W.-H. \& Elbrächter, M. (2017) Plate pattern clarification of the marine dinophyte Heterocapsa triquetra sensu Stein (Dinophyceae) collected at the Kiel Fjord (Germany). Journal of Phycology 53: $1305-1324$. https://doi.org/10.1111/jpy.12584

Turland, N.J., Wiersema, J.H., Barrie, F.R., Greuter, W., Hawksworth, D.L., Herendeen, P.S., Knapp, S., Kusber, W.-H., Li, D.-Z., Marhold, K., May, T.W., McNeill, J., Monro, A.M., Prado, J., Price, M.J. \& Smith, G.F. (2018) International Code of Nomenclature for algae, fungi, and plants (Shenzhen Code) adopted by the Nineteenth International Botanical Congress Shenzhen, China, July 2017. Regnum Vegetabile 159: 1-254. [Koeltz, Glashütten] https://doi.org/10.12705/Code.2018

Wetzel, J. (1885) Hofrath Friedrich Ritter von Stein. Lotos - Zeitschrift für Naturwissenschaften 34: XXIII-XXXII. 